\title{
Study on Talent Cultivation Mode and Teaching Methods Reform in Military Academics
}

\author{
Zeng Ying \\ Officers College Of CAPF, Chengdu 610213, China \\ zengying@163.com
}

Keywords: Military Academics; Talent Training; Curriculum System

Abstract. Military talents are those who have higher culture and scientific quality, much strong innovation consciousness and thinking ability. The overall objective of military talent training is to cultivate the comprehensive-quality military personnel that meet the requirements of military modernization and preparations for military struggle. In this paper, we construct the military talent training objectives model, and on this basis, we propose the innovative military talent training mode, from the perspective of curriculum content system and talent quality assurance system.

\section{Military Talent Training Objectives}

In March 2004, Chinese People's Liberation Army General Staff put forward Talent Training Objectives Model of Military Academies, presenting detailed explanation and analysis on the overall objectives and sub objectives of talent training in military academies. In general, talent training objectives model consists of overall objectives, sub objectives and the knowledge, ability, quality that support each sub objective. The concrete structure of military talent training objectives is shown in Figure 1:

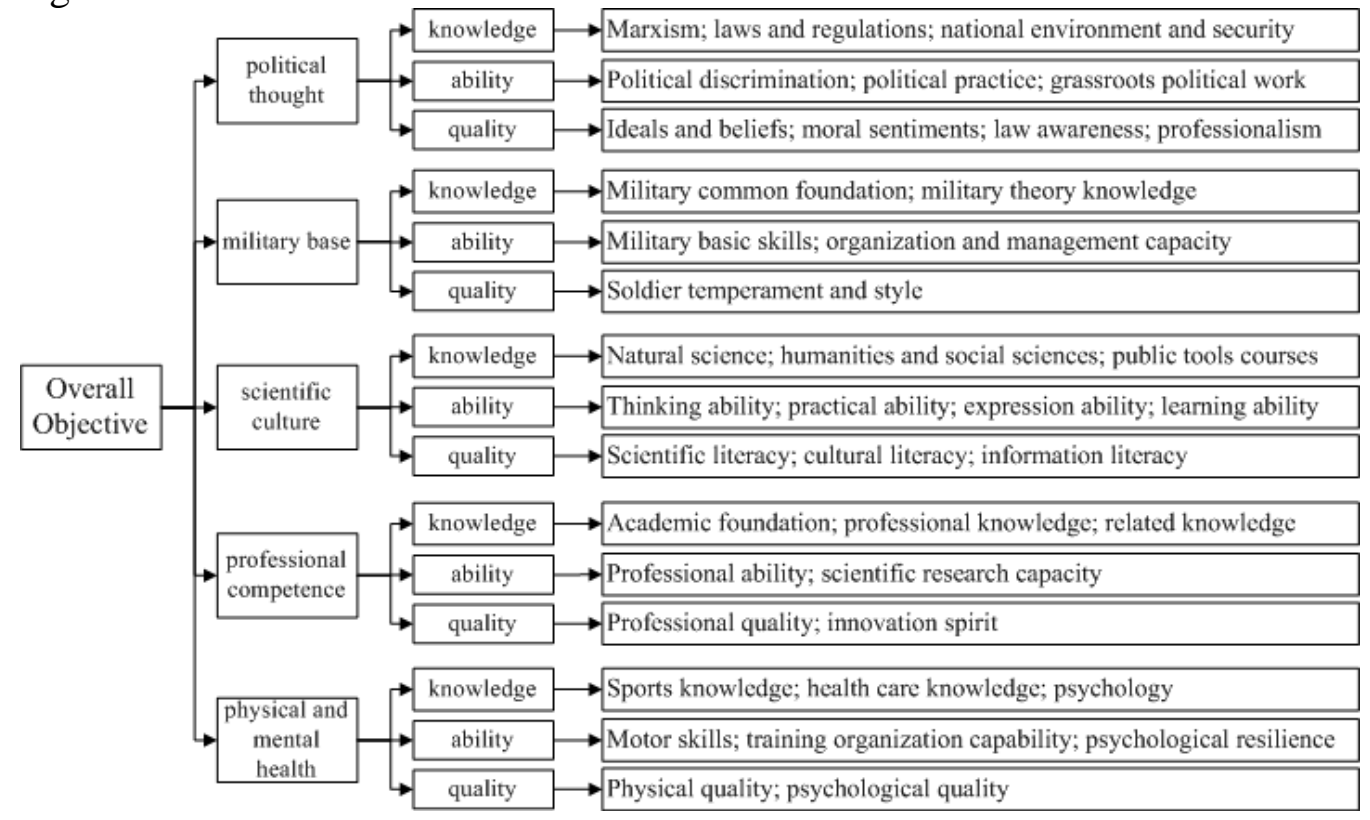

Figure 1. Concrete structure of military talent training objectives

As mentioned in the Talent Training Objectives Model of Military Academies, the overall objective of military talent training is through undergraduate education and officer basic training, to cultivate the comprehensive-quality military personnel that meet the requirements of military modernization and preparations for military struggle, and lay a solid foundation to serve as outstanding commanding officer, adviser, scientist or technical experts.

According to the model, under the overall objective, there are five sub objectives: political thought, military base, scientific culture, professional competence and physical and mental health. 
Each sub objective is decomposed into three elements: knowledge, ability and quality, and every element for its corresponding objective are supported by some specific essentials.

The general requirements and specific essentials of all the five sub objectives are shown in Table 1:

Table 1. Requirements and essentials of the sub objectives

\begin{tabular}{|c|c|c|}
\hline Sub Objective & Item & Description \\
\hline \multirow[b]{2}{*}{$\begin{array}{l}\text { political } \\
\text { thought }\end{array}$} & $\begin{array}{c}\text { general } \\
\text { requirements }\end{array}$ & $\begin{array}{l}\text { Clarify the basic standards in terms of political theory, political } \\
\text { behavior, occupation attitude and moral character, etc. }\end{array}$ \\
\hline & $\begin{array}{l}\text { specific } \\
\text { essentials }\end{array}$ & $\begin{array}{l}\text { (1) Master the basic principles of Marxism and related } \\
\text { humanities and social sciences knowledge; } \\
\text { (2) Possess the necessary ability of political and moral } \\
\text { behavior; } \\
\text { (3) Establish the correct ideals, beliefs and a good quality of } \\
\text { thought; } \\
\text { (4) Abide by the law, and obey orders. }\end{array}$ \\
\hline \multirow[b]{2}{*}{ military base } & $\begin{array}{l}\text { general } \\
\text { requirements }\end{array}$ & $\begin{array}{l}\text { Clarify the basic standards in terms of military basic } \\
\text { knowledge, basic skill and behavior criterion, etc. }\end{array}$ \\
\hline & $\begin{array}{l}\text { specific } \\
\text { essentials }\end{array}$ & $\begin{array}{l}\text { (1) Master military common knowledge and essential military } \\
\text { theory; } \\
\text { (2) Know the development situation and trends of military } \\
\text { science and technology; } \\
\text { (3) Master the necessary military skills; } \\
\text { (4) Have a certain organizational and command capabilities; } \\
\text { (5) Develop good soldier temperament and style. }\end{array}$ \\
\hline \multirow[b]{2}{*}{$\begin{array}{l}\text { scientific } \\
\text { culture }\end{array}$} & $\begin{array}{c}\text { general } \\
\text { requirements }\end{array}$ & $\begin{array}{l}\text { Clarify the basic standards in terms of scientific knowledge, } \\
\text { cognitive ability and cultural accomplishment, etc. }\end{array}$ \\
\hline & $\begin{array}{l}\text { specific } \\
\text { essentials }\end{array}$ & $\begin{array}{l}\text { (1) Systematically master the basic theory of natural science } \\
\text { and social science; } \\
\text { (2) Know the development trends of science and technology; } \\
\text { (3) Have strong thinking ability, practical ability, expression } \\
\text { ability, collaboration ability and ability to acquire knowledge; } \\
\text { (4) Possess good scientific literacy and cultural literacy. }\end{array}$ \\
\hline \multirow[b]{2}{*}{$\begin{array}{l}\text { professional } \\
\text { competence }\end{array}$} & $\begin{array}{c}\text { general } \\
\text { requirements }\end{array}$ & $\begin{array}{l}\text { Clarify the basic standards in terms of professional knowledge, } \\
\text { academic level, working ability and innovative quality, etc. }\end{array}$ \\
\hline & $\begin{array}{l}\text { specific } \\
\text { essentials }\end{array}$ & $\begin{array}{l}\text { (1) Systematically master the basic theory and basic knowledge } \\
\text { of the main discipline; } \\
\text { (2) Know the frontier of the main discipline; } \\
\text { (3) Have good basic skills of professional and the initial } \\
\text { capacity to engage in the practical work; } \\
\text { (4) Grasp the research methods of the main discipline, and have } \\
\text { preliminary scientific research ability; } \\
\text { (5) Have good professional quality, strong innovation sense } \\
\text { and wide professional adaptation. }\end{array}$ \\
\hline \multirow[b]{2}{*}{$\begin{array}{l}\text { physical and } \\
\text { mental quality }\end{array}$} & $\begin{array}{c}\text { general } \\
\text { requirements }\end{array}$ & $\begin{array}{l}\text { Clarify the basic standards in terms of physical quality and } \\
\text { mental state. }\end{array}$ \\
\hline & $\begin{array}{l}\text { specific } \\
\text { essentials }\end{array}$ & $\begin{array}{l}\text { (1) master the General knowledge of sports and psychology; } \\
\text { (2) have The basic skills of sports, good psychological } \\
\text { adjustment ability; } \\
\text { (3) good at organizing military training; } \\
\text { (4) have good Health awareness, strong physique and mental } \\
\text { health. }\end{array}$ \\
\hline
\end{tabular}




\section{Problems of Military Talent Training}

\section{Teaching Philosophy Deviation}

Currently, there is some deviation teaching philosophy in most of China's military academics. On the one hand, some education management personnel hold the wrong performance concept, who are keen to engage in vigorous activity, rather than management and education; on the other hand, the working method is usually too simple. The passive management mode is still very common in military academics, with the basic forms of command, control, supervision, restriction, etc. In training process, it concretely performances as some apparent formalism like queue, internal affairs, hygiene check, and military discipline, etc. However, as for deep-seated education and training like ideological guidance, study method impartment, mental health counseling, it does not get enough attention by the education management personnel.

\section{Imperfect Management Cadres Training Mechanism}

Management cadres play an important role in education and management of military academics. Meanwhile, they are also the makers and implementers of specialty setting, teaching plan establishment, curriculum system construction and regulations formulation. Therefore, the Comprehensive quality of the management cadres will directly determine the construction level of military academies. There are some general problems on management cadres training mechanism as follow.

First, the selection standard is not strict enough. Sometimes the management cadres are purely selected as the administrative cadres.

Second, the faculty is with irrational structure, and the source of faculty is unitary. It gives rise to the weak complementarity of faculty member in terms of experience and knowledge, which objectively restricts the management efficiency of overall faculty.

Third, the training mechanism is imperfect. The cultivation of management cadres is still not on the institutionalization and routine track.

\section{Immature Curriculum System}

Effective teaching must be based on scientific and rational curriculum system. However, influenced by traditional ideas and mode of talent training, curriculum system in china's military academics is with obvious signs of planned economy.

The universal problems of curriculum system in military academics are: too much theoretical courses, lack of operational practice courses, student weak in vocational skills, etc.

\section{Military Talent Cultivation Mode Innovation}

\section{Curriculum Content System}

Firstly, the curriculum content system in military academics should reflect the objectives and specifications of military talents. Objectives are the directional basis of curriculum content system, while specifications are the embodiment and refinement of objectives, which puts forward the specific requirements for the students.

Secondly, should consider the needs of military construction. The training objective of military academics has special directivity, because military talents serve directly to war and army construction. Therefore, the curriculum content system should combine with the actual needs of the development of the war and the construction of the army, to adjust the curriculum contents and organize the training.

Thirdly, the curriculum content system should base on present situation and development trend of military discipline. Teachers ought to encourage students to absorb more advanced knowledge from military science frontier, so as to become creative military talent who meet the needs of the changing times.

Finally, should take into account the restriction of the hours system. Universally, the number of hours in the curriculum system of military academics is subject to specific restrictions. Therefore, when design the curriculum content system, we must take everything into consideration and 
optimize the entirety, to resolve the contradiction between knowledge quantity increase and the limited hours.

The innovative curriculum content system of military talents training is shown in Figure 2:

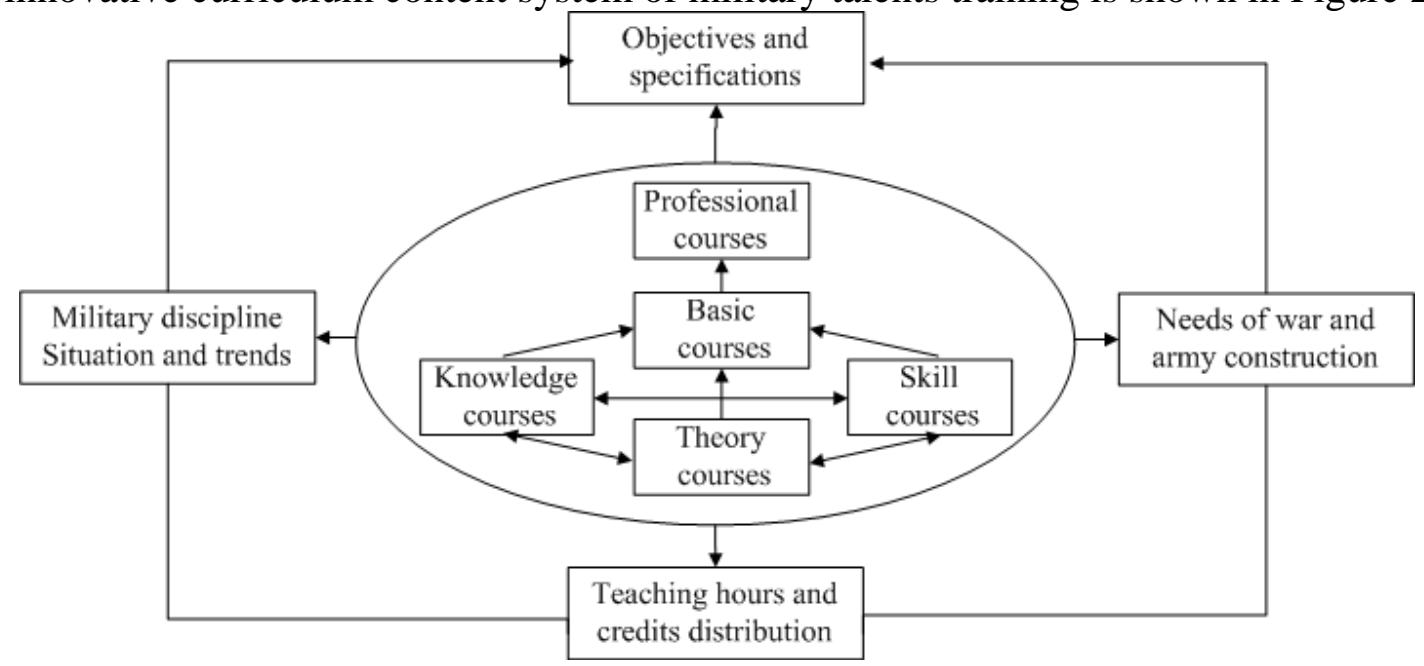

Figure 2. Innovative curriculum content system

\section{Talent Quality Assurance System}

Military talent quality assurance system is a huge system consisting of a series of elements: target system, organization system, monitoring system, evaluation system, etc. Talent quality assurance system is the material carrier and basic premise in the process of military talent cultivation. To construct, innovate and develop military talent quality assurance system can make full use of the existing educational resources potential in military academies, and effectively play the role of goal orientation, supervision, excitation, constraint, audit and evaluation, which would greatly improve the quality and efficiency of the army military personnel training institutions.

(1) Target System

Introduce ISO 9000 Quality management standards, to construct talent quality assurance system in military academics. Its target lies in: build a new teaching and management operation platform in military academics, so as to strengthen military talent quality consciousness and stimulate the vitality of military talent training. Through this platform, enthusiasm and creativity of students can be stimulated, and it also provides various means for teaching management personnel to participate in teaching activities.

(2) Organization System

To construct military talent quality assurance system, we should clarify the organization system, that is, the participators of the system. All the participators of military talent quality assurance system can be divided into three levels: the first level is management layer, mainly including integrated projects agency, teaching institutions bureau, and educational administration bureau; the second level is external cooperation layer, mainly referring to the teaching and scientific research institutions beyond the military academics; the third level is function body layer, including three bodies of teaching, administrative management and service assurance.

(3) Evaluation System

Scientific evaluation system is solid guarantee to carry forward the military talent quality assurance system, and ensure its efficient operation. Process evaluation method is helpful to objectively and accurately evaluate the operation efficiency of military talent training mode. Process evaluation method is to carry forward dynamic assessment and identification on every element of military talent quality assurance system, aiming at continuously improve the quality of military talent training and compete consummate the system.

\section{References}

[1] Peter Jarvis. Professional Education[M].UK: Croom Helm Ltd, 1983. 
[2] Edwin J-Arnold, JR. Professional Military Education Its Historical Development and Future Challenges [D].USA:U.S.ArinyWarCollege,1993.

[3] Franke V. Preparing for peace: Military identity, value orientations, and professional military education[M]. Greenwood Publishing Group, 1999.

[4] Bonk C J, Dennen V P. Massive multiplayer online gaming: A research framework for military education and training[J]. 2005.

[5] Murray N. The Role of Professional Military Education in Mission Command[J]. Joint Force Quarterly, 2014, 72.

[6] Chang J U, Lin C H. A Development of M-Learning Contents for Improving the Learning Ability of Military Education[J]. The Journal of the Institute of Webcasting, Internet and Telecommunication, 2012, 12(6): 25-32. 